\title{
PREPARATION AND SHELF LIFE STUDY OF PROBIOTIC CHOCOLATE MANUFACTURED USING LACTOBACILLUS HELVETICUS MTCC 5463
}

\author{
D. Gadhiya ${ }^{a}$, N.P. Shah ${ }^{b}$, A.R. Patel ${ }^{\text {b* }}$ and J.B. Prajapati ${ }^{a}$ \\ ${ }^{\text {a } D e p a r t m e n t ~ o f ~ D a i r y ~ M i c r o b i o l o g y, ~ S M C ~ C o l l e g e ~ o f ~ D a i r y ~ S c i e n c e, ~ A n a n d ~ A g r i c u l t u r e ~ U n i v e r s i t y, ~ A n a n d . ~ I n d i a ~}$ \\ bivision of Dairy and Food Microbiology, Mansinhbhai Institute of Dairy \& Food Technology-MIDFT, Mehsana. \\ India
}

(Received: 17 November 2017; accepted: 8 February 2018)

\begin{abstract}
Current study was taken up to develop probiotic chocolate using indigenous probiotic culture $L$. helveticus MTCC 5463. Preliminary trials included optimization of culture inoculums and physical form (freeze-dried or frozen concentrated) of addition and finally optimized product was tested for probiotic viability, texture, and organoleptic parameters at regular intervals during storage at $10 \pm 2{ }^{\circ} \mathrm{C}$ for 30 days. Probiotic chocolates prepared via incorporation of freeze dried culture $(3 \% \mathrm{w} / \mathrm{w})$ had acceptable organoleptic quality and had a similar behaviour as the control chocolate during storage. However, the viability of probiotic bacteria $\left(2.42 \times 10^{8} \mathrm{CFU} \mathrm{g}^{-1}\right)$ was achieved only up to 15 days of storage at $10 \pm 2{ }^{\circ} \mathrm{C}$.
\end{abstract}

Keywords: probiotics, chocolate, viability, freeze-dried culture, concentrated culture, shelf life

Lactic acid bacteria (LAB) possess many beneficial effects to promote human health. In the course of their proliferation and survival in gastrointestinal tract, probiotics produce metabolites such as lactic acid and antibiotic-like substances called bacteriocins that suppress the growth of putrefactive microorganisms. Their metabolic activities also help in the predigestion of food components, production of vitamins, and improve the bioavailability of minerals and other nutrients (ReKha \& ViJaYAlakshmi, 2010). Probiotic food products have got prime position in market.

Chocolate is a luxury food product universally popular among all age groups. It is reported that in 2015/2016 about 7.3 million tons of retail chocolate confectionery were consumed worldwide, with consumption expected to reach approximately 7.7 million tons by 2018/2019 (STATISTA, 2018). Probiotics incorporated chocolate could offer a good alternative to several dairy products broadening the health claims of chocolate based food products. Chocolate provides an encouraging role to human nutrition through provision of antioxidants, chiefly polyphenols (HII et al., 2009). Presence of biologically active phenolic compounds in cocoa has stimulated research on its effects in oxidative stress, ageing, blood pressure regulation, reduce heart disease risk, stroke, and atherosclerosis (BuITRAGo-LopEZ et al., 2011). Chocolate is a rich source of minerals and has been identified as an ideal carrier for probiotics (MAILLARD \& LANDUYT, 2008); found to absorb more probiotics compared to yoghurt (DEANNA, 2009). Chocolate being rich in cocoa butter provides protective passage for probiotics through the upper intestine to deliver them to the colon in sufficient numbers (LAHTinen et al., 2007). Specifically, the rheological behaviour and sensory perception of

* To whom correspondence should be addressed.

Phone: +00-91-2762243777; fax: +91-02762-253422; e-mail: amiamipatel@yahoo.co.in

0139-3006 (C) 2018 Akadémiai Kiadó, Budapest 
chocolates are influenced largely by its processing techniques, while particle size distribution, ingredient composition, and $\mathrm{pH}$ of the product are some factors that could affect probiotic growth and survival in food, and hence, the formulation can be manipulated to aid their efficacy (GADHIYA et al., 2015).

Indigenous strain L. helveticus MTCC 5463 has been proven to possess probiotic potentials with their specific beneficial role in the gastrointestinal tract and ability to reduce cholesterol and stimulate immunity (PRAJAPATI et al., 2011); thus, employed to prepare various probiotic and synbiotic fermented milk products in previous investigations (SHARMA, 2010; Shah \& Prajapati, 2013). Considering the popularity of chocolates and its rich nutrient content, the main objectives of our research were to standardize and optimize the process of manufacturing probiotic chocolate; and to evaluate the finished product based on physicochemical, sensory, and microbiological parameters followed by evaluating shelf life of the standardized product.

\section{Materials and methods}

\subsection{Probiotic strain and culture media}

The probiotic culture Lactobacillus helveticus MTCC 5463 was acquired from Dairy Microbiology Department, Anand Agricultural University, Anand. The lyophilized culture was propagated in sterilized reconstituted skim milk-RSM (10\% T.S.) by incubation at $37{ }^{\circ} \mathrm{C}$ for $8-12 \mathrm{~h}$ and stored at $5 \pm 2{ }^{\circ} \mathrm{C}$. Prior to use, three successive transfer of culture was administered into sterilized RSM following incubation at $37^{\circ} \mathrm{C}$ for $8-12$ h to keep it active.

\subsection{Preparation of concentrated and freeze dried culture}

About 2\% of activated culture of $L$. helveticus MTCC 5463 was inoculated in $100 \mathrm{ml}$ of de Man Rogosa Sharpe (MRS) broth and incubated at $37^{\circ} \mathrm{C}$ for $12 \mathrm{~h}$ in order to obtain sufficient cell mass. The cells were harvested by centrifugation at $4{ }^{\circ} \mathrm{C}, 5000$ r.p.m. for $15 \mathrm{~min}$, washed twice with saline water, and were stored at $-20^{\circ} \mathrm{C}$ in case of concentrated culture. For freeze drying, collected cells were inoculated into $10 \mathrm{ml}$ sterilized skim milk containing cryoprotectant (1\% glycerol), mixed thoroughly, distributed in glass vials, and frozen at -20 ${ }^{\circ} \mathrm{C}$ for overnight. Culture was freeze-dried using a freeze-dryer (Model Genesis SQ 25 Classic Super XL The Virtis Co., USA).

\subsection{Preparation of probiotic chocolate}

Probiotic chocolate was prepared as per the standard procedure given by ARAGON-Alegro and co-workers (2007) with some modifications. The final ingredients used to formulate chocolate based on sensory evaluation included: cocoa butter: 28 g, milk powder: 16 g, cocoa powder: 5 g, sugar: $48 \mathrm{~g}$, lecithin: $0.5 \mathrm{~g}$, and butter $5 \mathrm{~g}$ per $100 \mathrm{~g}$ of the chocolate. Further, the probiotic bacteria were incorporated in freeze dried form at $1-3 \% \mathrm{w} / \mathrm{w}$ of chocolate formulation.

1.3.1. Optimization of incorporation level and form of probiotic culture. Individually both forms of cultures, i.e. concentrated culture and freeze dried culture, of the probiotic bacterium were added at $0 \%, 1 \%, 2 \%$, and $3 \% \mathrm{w} / \mathrm{w}$ just before tempering at $40{ }^{\circ} \mathrm{C}$. Finished product was evaluated microbiologically and organoleptically. 


\subsection{Shelf life study}

The final probiotic chocolate was formulated with the best level of the above optimized parameters. The product was wrapped in aluminium foil for shelf-life study at $10 \pm 2{ }^{\circ} \mathrm{C}$ for 30 days. The periodic analysis of product was carried out at 0,15 , and 30 days for sensory, physicochemical, and microbiological parameters to determine its shelf life. The optimized product was compared with a standard reputed brand chocolate without probiotic, purchased from the market.

\subsection{Analysis of product}

1.5.1. Sensory evaluation. The sensorial attributes included were colour and appearance, flavour, body and texture, and overall acceptability criteria. Each parameter was judged on nine point hedonic scale ( 9 for liking extremely and 1 for disliking extremely). Fresh as well as stored products ( 15 and 30 days storage at $10 \pm 2{ }^{\circ} \mathrm{C}$ ) were marked randomly and brought to $15^{\circ} \mathrm{C}$ before giving for judging to an experienced and trained panel of 9 judges.

1.5.2. Microbiological analysis. Suitable dilutions were poured with respective agar media in sterile Petri dishes in duplicates. In addition to viable count of lactobacilli on MRS agar (after incubation at $37^{\circ} \mathrm{C} / 48 \mathrm{~h}$ under anaerobic conditions) (DE MAN et al., 1960), product was analysed for coliform count on Violet red bile agar - VRBA (after incubation at $37^{\circ} \mathrm{C} / 24-48 \mathrm{~h}$ under aerobic conditions), and yeast $\&$ mould count on Potato dextrose agar - PDA (after incubation at $28{ }^{\circ} \mathrm{C} / 5$ days under aerobic conditions) in order to judge the hygienic conditions during the product manufacturing process. Colony forming units (CFU) were counted from the respective plates following incubation under specific time-temperature combinations.

1.5.3. Compositional analysis. Compositional parameters of the finished product were measured as per the standard procedure described in AOAC 963.15 (31.4.02) (AOAC, 2002), Indian Standards IS: 9617, (1980), SP: 18, Part XI, (1981a), IS: 1479, Part II, (1961), and SP: 18, part XI, (1981b), respectively.

1.5.4. Texture profile analysis. Three samples of each experimental chocolates were subjected to uniaxial compression to $60 \%$ of the initial sample height, using a food texture analyzer of Lloyd Instruments LRX Plus material testing machine, England; fitted with 0-500 kg load cell. The force-distance curve obtained for a two-bite deformation cycle employing a Cross Head speed of $50 \mathrm{~mm} \mathrm{~min}^{-1}$, Trigger $0.1 \mathrm{~N}$, and $60 \%$ compression of the samples to determine various textural attributes of chocolate held for $15 \mathrm{~min}$ at $23 \pm 1{ }^{\circ} \mathrm{C}$ and $55 \%$ RH. The complete work of calculations of area under the force-distance curve, statistical analysis of data generated, and their conversion into various textural attributes were carried out by direct transfer of the data to Lloyd Instruments NEXYGEN data analysis and applications software.

\subsection{Statistical analysis}

All experiments were carried out in triplicate $(\mathrm{n}=3)$, and final data were analysed for variance by Completely Randomized Design (CRD) as per the methods described by STEEL and ToRRIE (1980). The significance was tested at five percent level using F-test, and CD percent was calculated. The values for microbial counts were log transformed before analysis. 


\section{Results and discussion}

\subsection{Formulation of probiotic chocolate}

2.1.1. Optimization and form of starter. Several trials were taken to decide the formulation of chocolate with the best organoleptic acceptance. Based on the consistency and textural characteristics of chocolate and the efficiency of uniform distribution of bacterial cells throughout the chocolate, the probiotic culture was decided to be mixed in just before tempering at $40{ }^{\circ} \mathrm{C}$. Addition of culture in concentrated form did not succeed even after several trials. The probable reason is the moisture content present in the culture form, which led to form non-uniform lumps and uneven dispersion resulting in formation of aggregates and prevention of proper moulding of chocolate. This phenomenon arises from an increase in friction between the particles of sweetener, which is in turn caused formation of a thin layer of syrup on the surface of their crystals (Chevalley, 1994; BecKett, 2000). Researchers reported the involvement of protein of lyophilizate, too. Further, the chocolate made with concentrated form of culture showed the absence of viable lactobacilli; indicating that the culture could not survive the tempering process. Incorporation of freeze dried form of culture was easier; it prevents moisture starving and facilitates the uniform mixing of culture with good flavour. Thus, the probiotic culture was decided to be added in the freeze dried form in further trials.

2.1.2. Optimization of incorporation level. The effect of addition of probiotic culture at different rates, e.g. $1 \%, 2 \%$, and $3 \%$ on sensory attributes was evaluated. None of the sensory parameters differed significantly $(\mathrm{P}<0.05)$ with respect to incorporation rates of probiotic culture. Although, the flavour, body and texture, colour and appearance, and overall acceptability scores were slightly higher for $1 \%$ as compared to $2 \%, 3 \%$, and control, only marginal differences were observed between all three rates of addition and control product. The flavour score ranged from 7.48 to 7.76 , while overall acceptability score was from 7.55 to 7.94. The average colour and appearance score was 8.13 , while body and texture score was 7.62. Overall, all the products were liked moderately to like very much by the panel of judges.

NEBESNy and co-workers (2005) indicated that yoghurt-containing and isomaltcontaining milk chocolates gained slightly higher average scores (4.82-4.90) than control sucrose-free chocolates (4.83-4.87). Sucrose-free yoghurt-containing dark chocolates received lower scores (4.73-4.75) than their yoghurt-free counterparts (4.82-4.86). Sensorial results of the chocolate mousse did not indicate any significant differences in preference between samples of mousses Control (C), Probiotic (P), and Synbiotic (S) as evaluated by 42 mousse consumers (Aragon-Alegro et al., 2007). Probiotic chocolate made with yoghurt powder (50\% and 100\%) was highly acceptable, similar to control sample, and the authors did not find any significant differences in attributes such as colour, gloss, and sweetness among all three samples (CHETANA et al., 2013).

Viable lactobacilli cells were proved through plate count technique and also by coagulation of milk at $1 \%$ within definite time period (7-8 h). Average counts of lactobacilli were $1.16 \times 10^{8}, 2.22 \times 10^{8}$, and $3.28 \times 10^{8} \mathrm{CFU} \mathrm{g}^{-1}$ with $1 \%, 2 \%$, and $3 \%$ culture addition, respectively. According to Boylston and co-workers (2004), the recommended level of probiotic microorganisms in food at the time of consumption is $10^{6} \mathrm{CFU} \mathrm{g}{ }^{-1}$ to have beneficial effects on the consumer's health. Incorporation of probiotic culture at higher levels did not show any undesirable effect on the sensory attributes, and hence it was decided to proceed 
with 3\% as well. Absence of coliforms and yeast and mould counts indicate that the controlled hygienic conditions were maintained during preparation of probiotic chocolate.

\subsection{Shelf life study and analysis of product}

2.2.1. Composition of product. The proximate composition of finalized product is shown in Table 1 . The major portion of chocolate consists of fat and carbohydrate followed by protein and moisture. The average relative humidity (RH) of the chocolate was $0.53 \%$. According to Possemiers and co-workers (2010), value of total protein, milk protein, carbohydrates, total fat, and polyphenols were $7.0,5.7,50.9,36.7$, and $0.3 \%$, respectively, in the milk chocolate matrix.

Table 1. Proximate composition of probiotic chocolate

\begin{tabular}{llc}
\hline No. & Constituent & Concentration $(\mathrm{w} / \mathrm{w} \%)$ \\
\hline 1 & Carbohydrate & $59.38 \pm 0.30$ \\
2 & Fat & $31.07 \pm 0.30$ \\
3 & Protein & $5.87 \pm 0.13$ \\
4 & Moisture & $2.28 \pm 0.36$ \\
5 & Ash & $0.86 \pm 0.31$ \\
& Water activity (RH \%) & $0.53 \pm 0.02$ \\
\hline
\end{tabular}

2.2.2. Texture analysis. The data shown in Table 2 are the mean values of hardness, cohesiveness, gumminess, chewiness, and adhesiveness (stickiness) of probiotic chocolate. NEBESNY and co-workers (2007) observed non-significant difference between Lactobacillusfree and Lactobacillus-containing chocolate masses with different fat contents; the average value of destructive tension was $6.85 \mathrm{MPa}$, and the average value of destructive force was $65.93 \mathrm{~N}$ for all batches of chocolate.

Table 2. Texture analysis of probiotic chocolate

\begin{tabular}{llc}
\hline No. & Texture attributes & Readings \\
\hline 1 & Hardness (N) & 154.22 \\
2 & Cohesiveness & 0.01 \\
3 & Chewiness (Nmm) & 2.97 \\
4 & Gumminess (N) & 1.46 \\
5 & Adhesiveness (Nmm) & 0.01 \\
\hline
\end{tabular}

2.2.3. Sensory evaluation. Tables 3-6 show the comparison between treatment and control product for changes in flavour, colour and appearance, body and texture, and overall acceptability scores. The initial average score was significantly higher $(\mathrm{P}<0.05)$ in control than probiotic chocolate. The decline in score for probiotic chocolate was slower during the first 15 days of storage for all sensory parameters. On the $15^{\text {th }}$ day, colour and appearance score significantly $(\mathrm{P}<0.05)$ declined in probiotic chocolate. The rate of decline in score for 
flavour, colour and appearance, body and texture, and overall acceptability was faster during the last fifteen days of storage. The major reason behind decrease in colour and appearance, body and texture score, and sugar blooms score could be ascribed to the development of uneven fat, fat and sugar bloom in the probiotic chocolate. Control chocolate showed significantly higher average score for all sensory attributes than probiotic chocolate during the entire storage period, however, both followed the same pattern of decrease in acceptability scores. The average flavour, colour and appearance, body and texture, and overall acceptability score was 7.00, 7.64, 7.09, and 7.20, respectively, in probiotic chocolate on the $30^{\text {th }}$ day of storage. However, the probiotic chocolate had still received acceptability.

Table 3. Changes in flavour score of probiotic chocolate

\begin{tabular}{|c|c|c|c|c|}
\hline \multirow[t]{2}{*}{ Treatment (T) } & \multicolumn{3}{|c|}{ Storage period, days (P) } & \multirow[t]{2}{*}{ Treatment mean } \\
\hline & 0 & 15 & 30 & \\
\hline Control & 7.90 & 8.17 & 7.93 & 8.00 \\
\hline Probiotic & 7.47 & 7.06 & 6.47 & 7.00 \\
\hline Period mean & 7.68 & 7.62 & 7.20 & \\
\hline \multicolumn{5}{|c|}{ ANOVA table } \\
\hline Source & S EM & & CD & TEST \\
\hline $\mathrm{T}$ & 0.09 & & 0.26 & $*$ \\
\hline $\mathrm{P}$ & 0.10 & & 0.32 & $*$ \\
\hline $\mathrm{T} \times \mathrm{P}$ & 0.15 & & 0.46 & $*$ \\
\hline CV\% & \multicolumn{4}{|c|}{3.43} \\
\hline
\end{tabular}

*: significant at $\mathrm{P}<0.05$

Table 4. Changes in colour and appearance of probiotic chocolate during storage

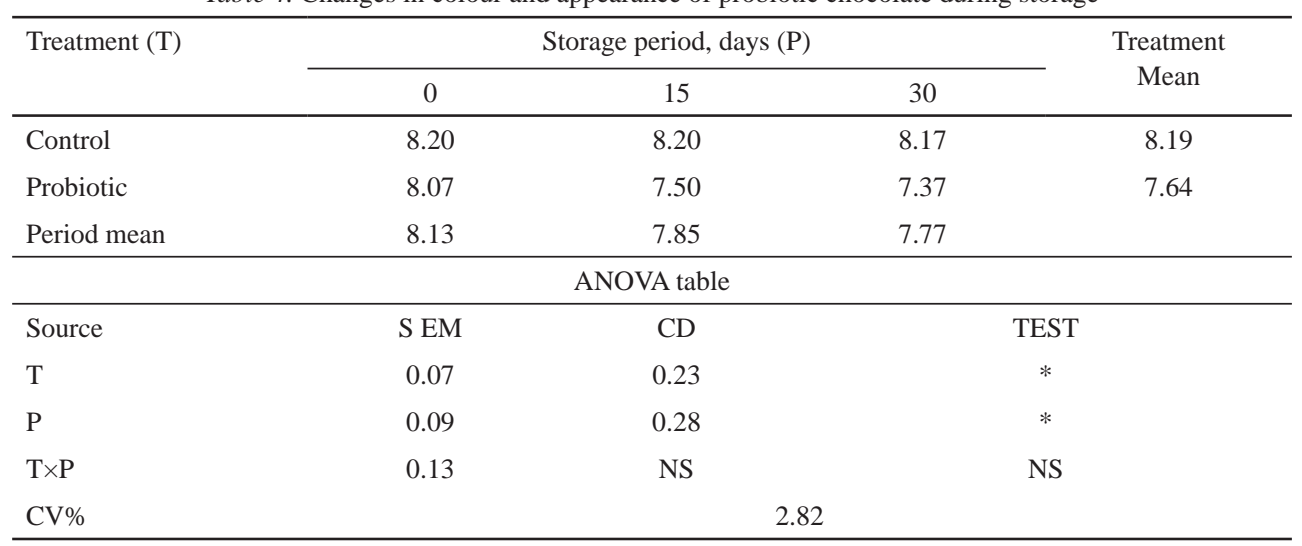

*: significant at $\mathrm{P}<0.05$; NS: not significant 
Table 5. Changes in body and texture of probiotic chocolate during storage

\begin{tabular}{|c|c|c|c|c|}
\hline \multirow[t]{2}{*}{ Treatment (T) } & \multicolumn{3}{|c|}{ Storage period, days (P) } & \multirow[t]{2}{*}{ Treatment mean } \\
\hline & 0 & 15 & 30 & \\
\hline Control & 7.67 & 8.27 & 7.90 & 7.94 \\
\hline Probiotic & 7.47 & 7.47 & 6.33 & 7.09 \\
\hline Period mean & 7.57 & 7.87 & 7.11 & \\
\hline \multicolumn{5}{|c|}{ ANOVA table } \\
\hline Source & & S EM & CD & TEST \\
\hline $\mathrm{T}$ & & 0.07 & 0.20 & $*$ \\
\hline $\mathrm{P}$ & & 0.08 & 0.25 & $*$ \\
\hline $\mathrm{T} \times \mathrm{P}$ & & 0.11 & 0.35 & $*$ \\
\hline $\mathrm{CV} \%$ & & & 2.64 & \\
\hline
\end{tabular}

*: significant at $\mathrm{P}<0.05$

Table 6. Changes in overall acceptability of probiotic chocolate during storage at $10 \pm 2{ }^{\circ} \mathrm{C}$

\begin{tabular}{|c|c|c|c|c|}
\hline \multirow[t]{2}{*}{ Treatment (T) } & \multicolumn{3}{|c|}{ Storage period, days (P) } & \multirow{2}{*}{$\begin{array}{c}\text { Treatment } \\
\text { Mean }\end{array}$} \\
\hline & 0 & 15 & 30 & \\
\hline Control & 7.93 & 8.43 & 7.93 & 8.10 \\
\hline Probiotic & 7.57 & 7.33 & 6.70 & 7.20 \\
\hline Period mean & 7.75 & 7.89 & 7.31 & \\
\hline \multicolumn{5}{|c|}{ ANOVA table } \\
\hline Source & SEM & $\mathrm{CD}$ & & TEST \\
\hline $\mathrm{T}$ & 0.03 & 0.10 & & * \\
\hline $\mathrm{P}$ & 0.04 & 0.13 & & * \\
\hline $\mathrm{T} \times \mathrm{P}$ & 0.06 & 0.19 & & * \\
\hline $\mathrm{CV} \%$ & \multicolumn{4}{|c|}{1.38} \\
\hline
\end{tabular}

*: significant at $\mathrm{P}<0.05$

NeBESNY and co-workers (2007) reported that addition of lyophilized preparation of $L$. casei and $L$. paracasei did not change the sensory attributes of chocolate. Sensory attributes of the examined batches of lyophilizate containing chocolate received $4.83-4.86$ points in the five-point scale, which was almost the same as that of the reference, Lactobacillus-free batches of chocolate.

2.2.4. Changes in microbiological quality. The average lactobacilli count in freshly prepared chocolate was $3.72 \times 10^{8} \mathrm{CFU} \mathrm{g}^{-1}$ which can be considered as a sufficient probiotic dosage. The count declined to $2.42 \times 10^{8} \mathrm{CFU} \mathrm{g}^{-1}$ during the first 15 days of storage. However, the cell count had fallen below 1000 on the $30^{\text {th }}$ day. To confirm this observation, $1 \mathrm{~g}$ of chocolate was suspended in $100 \mathrm{ml}$ sterile skim milk and was incubated at $37^{\circ} \mathrm{C}$. After $24 \mathrm{~h}$, the milk was found in coagulated form having $0.7 \%$ lactic acid. The cells were not capable to form colonies while plated on MRS. It is difficult to give the exact reason for this, but it could 
be attributed to the complex internal structure of chocolate, comprising of high fat \& carbohydrate (osmotic tension), very low $\mathrm{a}_{\mathrm{w},}$ and temperature, which may cause injury to the cells and restrict cell multiplication (MatTILA-SAndHolm \& SKYTTA, 2002).

Lactobacillus cells are sensitive to the adverse environment present in chocolate (NEBESNy et al., 2005). MANDAL and co-workers (2005) incorporated microencapsulated $L$. casei NCDC 298 and inulin in milk chocolate. After 30 days of storage at room temperature, the lactobacilli counts decreased by approximately 3 and 2 log cycles from an initial level $\left(8 \log \mathrm{CFU} \mathrm{g}{ }^{-1}\right)$ in products with free and encapsulated lactobacilli, respectively; however, at refrigeration temperature the viability of free as well as encapsulated lactobacilli was unchanged for 60 days. Results obtained are in harmony with findings of NEBESNY and coworkers (2005; 2007). The absence of yeast \& mould and coliforms in freshly prepared as well as stored samples indicate that hygienic conditions and environment were maintained during preparation and the whole storage period.

\section{Conclusions}

Current trend in the diversification of probiotic foods is towards the non-fermented and heattreated food products; probiotic milk chocolate is a relatively innovative addition to the growing list of functional foods. Results of preliminary studies suggested that incorporation of freeze dried cells had better uniformity and distribution among the ingredients compared to concentrated form of cells. Furthermore, the rate of culture inoculums in the finished product had a non-significant effect on the sensory attributes, therefore, higher amounts of inoculum $(3 \% \mathrm{w} / \mathrm{w})$ were used to achieve higher probiotic count in the final product. Probiotic chocolate developed in the present investigation had a similar behaviour as the control chocolate during 30 days of storage. Though it had an acceptable organoleptic quality till 30 days, the probiotic bacteria remained viable only up to 15 days (viz. $2.42 \times 10^{8} \mathrm{CFU} \mathrm{g}^{-1}$ ), and their amounts further decreased to about $1000 \mathrm{CFU} \mathrm{g}{ }^{-1}$ after 30 days of storage at $10 \pm 2{ }^{\circ} \mathrm{C}$. Thus, in the future, we aim to use microencapsulation technique in order to improve the probiotic viability in the finished product.

\section{References}

Aragon-Alegro, L.C., Alegro, J.H.A., Cardarelli, H.R., Chiu, M.C. \& SaAd, S.M.I. (2007): Potentially probiotic and synbiotic chocolate mousse. LWT - Food Sci. Technol., 40, 669-675.

AOAC (2002): Official methods of analysis of the Association of Official Analytical Chemists. 13th ed. Washington. Beскетт, S.T. (2000): The science of chocolate. The Royal Society of Chemistry, Cambridge, pp. 1-7.

Boylston, T.D., Vinderola, C.G., Ghoddusi, H.B. \& Reinheimer, J.A. (2004): Incorporation of bifidobacteria into cheeses: Challenges and rewards. Int. Dairy J., 14, 375-387.

Buitrago-Lopez, A., Sanderson, J., Johnson, L., Warnakula, S., Wood, A., Di Angelantonio, E. \& Franco, O.H. (2011): Chocolate consumption and cardiometabolic disorders: Systematic review and meta-analysis. BMJ Brit. Med. J., 343, d4488.

Chetana, R., Reddy, S.R.Y. \& Negi, P.S. (2013): Preparation and properties of probiotic chocolates using yoghurt powder. Food Nutr. Sci., 4, 276-281.

Chevalley, J. (1994): Chocolate flow properties. -in: BeСKeTt, S.T. (Ed.) Industrial chocolate manufacture and use. Chapman and Hall, New York, pp. 139-154.

de Man, J.C., Rogosa, M. \& Sharpe, M.E. (1960): A medium for the cultivation of lactobacilli. J. Appl. Bacteriol., 23, 130-135. 
DeAnna (2009): Maramor premium milk \& dark chocolate with probiotics. Blog. http://www.chocablog.com/ reviews/maramor-premium-milk-dark-chocolate-with-probiotics/ (last accessed 18.01.2018)

Gadhiya, D., Patel, A. \& Prajapati, J.B. (2015): Current trend and future prospective of functional probiotic milk chocolates and related products - A review. Czech J. Food Sci., 33, 295-301.

HiI, C.L., Law, C.L., Suzannah, S., Miswani, S. \& Cloke, M. (2009): Polyphenols in cocoa (Theobroma cacao L.). Asian J. Food Agro-Ind., 2, 702-722.

Indian StANDARDS (1961): Methods of testing for dairy industry. Part II. Rapid examination of milk. Indian Standards Institution, New Delhi. IS: 1479 (Part II)

Indian Standards (1980): Specification for dahi. Indian Standards Institution, New Delhi. IS: 9617

Indian Standards (1981a): Determination of fat by Gerber method. Part I. Indian Standards Institution, New Delhi. IS: $1224-1$

Indian StandARDS (1981b): Handbook of food analysis (part XI). Indian Standards Institution, New Delhi. IS: SP: 18 Lahtinen, S.J., Ouwehand, A.C., Salminen, S.J., Forssell, P. \& Myllärinen, P. (2007): Effect of starch- and lipidbased encapsulation on the culturability of two Bifidobacterium longum strains. Lett. Appl. Microbiol., 44, 500-505.

Maillard, M. \& Landuyt, A. (2008): Chocolate: An ideal carrier for probiotics. Agro Food Ind. Hi Tec., 19(3). $13-15$.

Mandal, S., PuniYa, A.K. \& Singh, K. (2005): Value addition of milk chocolate using inulin and encapsulated Lactobacillus casei NCDC-298. National seminar on value added dairy products, 21-22 Dec, 2005, Dairy Technology Society of India, N.D.R.I., Karnal, India. SQM 20, p. 186.

Mattila-Sandholm, T. \& SkytTA, E. (2002): The effect of spoilage flora on the growth of food pathogens in minced meat stored at chilled temperatures. LWT - Food Sci. Technol., 24, 116-120.

Nebesny, E., Zyzelewicz, D., Motyl, I. \& Libudzisz, Z. (2005): Properties of sucrose-free chocolates enriched with viable lactic acid bacteria. Eur. Food Res. Technol., 220, 358-362.

Nebesny, E., Zyzelewicz, D., MotyL, I. \& Libudzisz, Z. (2007): Dark chocolates supplemented with Lactobacillus strains. Eur. Food Res. Technol., 225, 33-42

Possemiers, S., Marzorati, M., Verstraete, W. \& Van De Wiele, T. (2010): Bacteria and chocolate: A successful combination for probiotic delivery. Int. J. Food Microbiol., 141, 97-103.

Prajapati, J.B., Khedkar, C.D., Chitra, J., Suja, S., Mishra, V., Sreeja, V. et al. (2011): Whole-genome shotgun sequencing of an Indian-origin Lactobacillus helveticus strain, MTCC 5463, with probiotic potential. J. Bacteriol., 193, 4282-4283.

Rekha, C.R. \& Vijayalakshmi, G. (2010): Bioconversion of isoflavone glycosides to aglycones, mineral bioavailability and vitamin B complex in fermented soymilk by probiotic bacteria and yeast. J. Appl. Microbiol., 109, 1198-1208.

Shah, N. \& PrajAPATI, J.B. (2013): Effect of carbon dioxide on sensory attributes, physico-chemical parameters and viability of probiotic L. helveticus MTCC 5463 in fermented milk. J. Food Sci. Tech., 51, 3886-3893.

Sharma, S. (2010): Development of synbiotic lassi with honey as prebiotic. B. Tech. Thesis, Anand Agricultural University, Anand, Gujarat State, India. 151 pages.

STATISTA (2018): Statista report: Consumption of retail chocolate confectionery worldwide 2012/13-2018/19. https://www.statista.com/statistics/238849/global-chocolate-consumption/ (last accessed on 22/01/2018)

Steel, R.G.D. \& Torrie, J.H. (1980): Principles and procedure of statistics - A biometrical approach. $2^{\text {nd }}$ ed. McGraw-Hill Kogakusha Ltd., Japan. p. 137. 